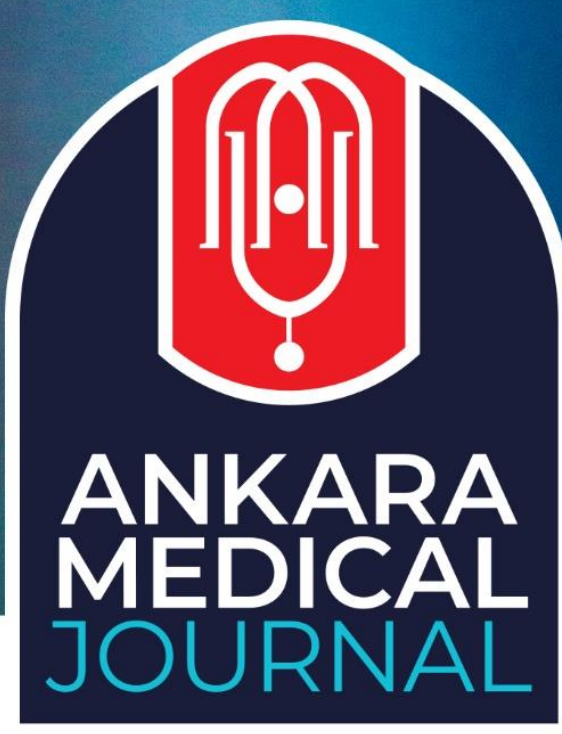

Research Article

Ankara Med J, 2021;(1):134-149 // (60) 10.5505/amj.2021.04207

\title{
CHEST CT FINDINGS AND THEIR CORRELATION WITH RT-PCR TESTING IN PEDIATRIC COVID-19 PATIENTS
}

\section{PEDİATRİK COVID-19 HASTALARINDA TORAKS BT BULGULARI VE RT-PCR TEST SONUÇLARI İLE KORELASYONU}

\author{
(D) Gülşah Bayram Ilıkan', (D) Şükriye Yılmaz ${ }^{1}$ \\ ${ }_{1}^{1}$ Department of Radiology, Ankara City Hospital, Ankara
}

Yazıșma Adresi / Correspondence:

Uzm. Dr. Gülşah Bayram Ilıkan (e-mail: gulsahbayram@hotmail.com)

Geliş Tarihi (Submitted): 31.12.2020 // Kabul Tarihi (Accepted): 03.03.2021

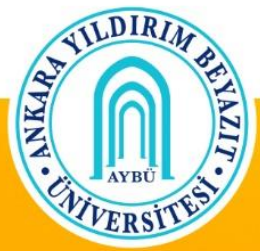

Ankara YIIdrrm Beyazıt University Faculty of Medicine Department of Family Medicine 


\section{Öz}

Amaç: COVID-19 ön tanısı olan çocuk hastalarda revers transkriptaz-polimeraz zincir reaksiyon (RT-PCR) testi sonuçları ile toraks bilgisayarlı tomografi (BT) bulgularını karşılaştırmak.

Materyal ve Metot: Retrospektif olarak, 177 çocuk hastada toraks BT bulguları ve RT-PCR test sonuçları değerlendirildi. Test sonuçlarına göre hastalar 'COVID-19 pozitif' ve 'COVID-19 negatif' olmak üzere iki gruba ayrild.

Bulgular: COVID-19 pozitif grupta hastaların \%65,71'inin ailesinde COVID-19 tanısı bulunmaktaydı ( $\mathrm{p}<0.01$ ). Aynı grupta BT bulguları normal olan hastaların \%50'si 16 yaşından küçüktü $(\mathrm{p}<0,01)$ ve en sık tek lob tutulumu izlenmekteydi $(\% 54,54, \mathrm{p}<0.01)$. Her iki grupta en sik izlenen BT bulgusu konsolidasyon ile birlikte buzlu cam dansitesi (BCD) idi. Fibrotik bantlar (\% 51,46; $\mathrm{p}<0,01)$, retiküler patern $(\% 34,95 ; \mathrm{p}<0,01)$, atelektazi (\% 9,71, p<0.01), mozaik perfüzyon (\% 26,21, p<0.01), ve plevral effüzyon (\% 19,42, p<0.01) COVID-19 negatif grupta daha sık izlendi. Altta yatan hastalığı bulunanlarda BT'nin sensitivitesi 0,441 , RT-PCR testin ise 0,863 olarak hesapland..

Sonuç: Ailesinde COVID-19 hastalığı olan çocuklarda en sık BT bulgusu konsolidasyonun eşlik ettiği ya da etmediği fokal BCD’dir. BT bulguları yaygın ve şiddetli ise hasta yüksek olasılıkla COVID-19 değildir. Altta yatan kronik hastalığı olan çocuklarda RT-PCR testi, tanı koymada BT'den daha duyarlıdır.

Anahtar Kelimeler: Bilgisayarlı tomografi, COVID-19 pnömonisi, pediatrik, revers transkripsiyon polimeraz zincir reaksiyon testi.

\section{Abstract}

Objectives: To compare the reverse transcription-polymerase chain reaction (RT-PCR) test results and chest computerized tomography (CT) findings in pediatric patients with a pre-diagnosis of COVID-19.

Materials and Methods: The thorax CT examinations and RT-PCR test results were retrospectively evaluated in 177 children. According to the test results, the patients were divided into two groups as 'COVID-19-positive' and 'COVID-19-negative'.

Results: In the COVID-19-positive group, $65.71 \%$ of the patients with a family history of COVID-19 (p<0.01). In the same group, $50.00 \%$ of patients with normal CT findings were older than 16 years $(\mathrm{p}<0.01)$, and singlelobe involvement was more common $(54.54 \%, \mathrm{p}<0.01)$. The most observed CT finding was consolidation with ground-glass opacities (GG0) in both groups. Fibrotic bands $(51.46 \%, \mathrm{p}<0.01)$, reticular pattern $(34.95 \%$, $\mathrm{p}<0.01)$, atelectasis $(9.71 \%, \mathrm{p}<0.01)$, mosaic perfusion $(26.21 \%, \mathrm{p}<0.01)$, and pleural effusion $(19.42 \%$, $\mathrm{p}<0.01$ ) were mostly seen in the COVID-19-negative group. In patients with underlying diseases, the sensitivity values were calculated as 0.441 for CT and 0.863 for the RT-PCR test.

Conclusion: In patients with a family history of COVID-19, the chest CT showed focal GGO with or without consolidation as the most common finding. If CT findings diffuse and severe, the patient most likely does not have COVID-19. The RT-PCR test results are more reliable than CT in children with underlying diseases.

Keywords: Computerized tomography, COVID-19 pneumonia, pediatrics, reverse transcription-polymerase chain reaction test. 


\section{Introduction}

Coronavirus disease 2019 (COVID-19), which emerged in the world in December 2019, has rapidly spread and become a pandemic. In Turkey, the first case was diagnosed on March 10, 2020, and according to official data, the number of positive cases reached 163,042 by June 1, 2020. 1,2 It is known that globally, pediatric COVID-19 cases are less common and their clinical presentation is more favorable compared to adults. ${ }^{3,4}$ Although children mostly contract the virus from their families, the excretion of the virus lasts longer than in the other family members; therefore, they play an important role in the spread of the disease. ${ }^{5-9}$ Besides, considering that the disease can progress and result in the development of lung damage in case of late diagnosis and treatment, early diagnosis is important in this age group with a long life expectancy. ${ }^{3}$ The reverse transcriptionpolymerase chain reaction (RT-PCR) test by a nasal-oropharyngeal swab is accepted as the definitive diagnostic method. Although this test is still not widely used worldwide, there are studies reporting that its reliability rate is between 60 and $80 \% .{ }^{10,11}$ It is also emphasized that a thorax computerized tomography (CT) is more reliable in diagnosis; however, it is necessary to approach a CT examination cautiously, especially in pediatric patients due to the risks involved in radiation exposure. CT findings can be confusing in patients with underlying chronic diseases, such as immunodeficiency or primary malignancy. Also, the differential diagnosis of the disease becomes difficult in this seasonal period when the incidence of other viral upper respiratory tract infections increases. ${ }^{12}$ In this study, we aimed to evaluate the thorax CT findings in pediatric patients, who underwent the RT-PCR test due to the clinical suspicion of COVID-19 pneumonia, to determine the location of CT in the diagnosis and differential diagnosis of this disease in this patient group and to compare the sensitivity of the CT and RT-PCR tests.

\section{Materials and Methods}

In our hospital, between 10 March and 30 May 2020, 177 pediatric patients, who underwent both the RT-PCR test and thorax CT as part of clinical examinations with the suspicion of COVID-19 pneumonia, were analyzed. The RT-PCR test was performed on the nasal-oropharyngeal swabs. Patients with an RT-PCR test result but without a thorax-CT examination were not included in the study. All patients admitted to the hospital were evaluated according to the COVID-19 guidelines released by the Turkish Ministry of Health. ${ }^{13}$ Informed written consent was obtained from the parents of all patients prior to CT. The age, gender, underlying chronic diseases, and RT-PCR test results of the symptomatic (fever, cough, sore throat, etc.) patients and those with a family history of COVID-19 were recorded.

Thin-section, non-contrast, low-dose thorax CT examinations were performed in the patients (Revolution, GE medical system, Germany). The tomography protocol according to the age range was as follows: $80 \mathrm{kV}$ and 120 $\mathrm{mA}$ for $0-1$ years, $80 \mathrm{kV}$ and $160 \mathrm{~mA}$ for 2-6 years, $100 \mathrm{kV}$ and $200 \mathrm{~mA}$ for 6-10 years, $100 \mathrm{kV}$ and $250 \mathrm{~mA}$ for 
in 10-18 years, and slice thickness was $2.5 \mathrm{~mm}$ in all cases. Images with a slice thickness of $0.625 \mathrm{~mm}$ were obtained by reconstruction. The sections were evaluated by two specialist radiologists (GBI and SY) with 12 and 8 years of experience in pediatric radiology.

The patients were divided into two groups as COVID-19-positive and COVID-19-negative according to the RTPCR test results. Parenchymal pneumonic involvement was divided into four groups: 1) ground-glass opacities (GGO), 2) consolidation, 3) GGO with consolidation, and 4) consolidation with the tree-in-bud sign. In addition, the halo sign, bronchiectasis, bronchial wall thickness, air-bronchogram, pulmonary nodule, mosaic perfusion, emphysema, reticular pattern (or interseptal thickening), fibrotic bands, atelectasis, pleural effusion, and pneumothorax were evaluated as accompanying findings. The CT findings were compared with the RT-PCR test results. Statistical analyses were performed using SPSS version 20. The student's t-test was performed to test the differences between the groups.

\section{Results}

The patients' ages ranged from 2 months to 18 years (mean 10.05 years), and $52.54 \%$ of the patients were male (93/177) and 47.46\% (84/177) were female (Table 1). The RT-PCR test was performed on the nasaloropharyngeal swabs three times on average (range, 1-5). The RT-PCR test was negative in 142 (80.23\%) patients. There were 45 patients with a COVID-19 diagnosis of at least one member in the family (defined as family history). In the COVID-19-positive group, 65.71\% of the patients with a family history of COVID-19. The rate of a family history of COVID-19 was significantly higher in the COVID-19-positive group (p<0.01). RT-PCR test was positive in 51.11\% (23/45) of children with family history and negative in 48.89\% (22/45) (p=0.342). The CT findings were normal in 75.55\% (34/45) of children with family history and pathological in $24.44 \%$ (11/45). The RT-PCR test was positive in 19 (42.22\%) and negative in 15 (33.33\%) symptomatic patients with family history and normal thorax CT findings $(\mathrm{p}=0.504)$.

The presence of fever and cough was the most common clinical finding in the COVID-19- positive group $(45.71 \%, 16 / 35)$. No relation was found between the presence of clinical and CT findings $(\mathrm{p}=0.221)$.

Underlying diseases were observed in 39.55\% (70/177) of patients and were mostly in the form of hematological diseases (leukemia, aplastic anemia, thalassemia, autoimmune hemolytic anemia, etc.) (24.29\%, 17/70), followed by respiratory system diseases (bronchopulmonary dysplasia, asthma, primary ciliary dyskinesia, tuberculosis, asphyxiating thoracic dystrophy, etc.) $(22.86 \%, 16 / 70)$. The patients who received chemotherapy due to primary malignancies (lymphoma, neuroblastoma, Ewing's sarcoma, osteosarcoma, rhabdomyosarcoma, Wilms' tumor, germ cell tumor, hepatocellular carcinoma, glioblastoma multiforme, etc.) and those had immune system problems due to various diseases or steroid therapy (Stevens-Johnson 
syndrome, chronic granulomatous disease, malnutrition, etc.) constituted $21.43 \%$ (15/70) of the sample. Due to cerebral palsy or other neurological diseases, $18.57 \%(13 / 70)$ of patients were using mechanical ventilators. Furthermore, 5.71\% (4/70) of the patients had renal insufficiency and 7.14\% (5/70) had cardiac problems. The RT-PCR was negative in $97.14 \%$ (68/70) of children with underlying diseases $(\mathrm{p}<0.01)$.

Table 1. Distribution of the patient data by the reverse transcription-polymerase chain reaction (RT-PCR) test results

\begin{tabular}{|l|c|c|}
\hline & COVID-19-positive $(\mathrm{n}=35)$ & COVID-19-negative $(\mathrm{n}=142)$ \\
\hline Age $($ mean) & 10.07 & 10.01 \\
\hline Sex (Male/female) & $19 / 16$ & $74 / 68$ \\
\hline Family history & $\mathbf{2 3 ( 6 5 . 7 1 \% ) ^ { * }}$ & $22(15.49 \%)$ \\
\hline Underlying diseases & $2(5.71 \%)$ & $\mathbf{6 8 ( 4 7 . 8 9 \% )} *$ \\
\hline
\end{tabular}

${ }^{*} \mathrm{p}<0.01$, Student's t-test

In 31 of the patients in the COVID-19-negative group, other factors that caused pneumonia were detected in the viral panel, which was examined from the tracheal aspirate [Hemophilus influenza type $B(n=3)$, rhinovirus $(n=6)$, enterovirus $(n=4)$, adenovirus $(n=3)$, human bocavirus $(n=2)$, cytomegalovirus $(n=6)$, klebsiella pneumonia $(n=2)$, parvovirus B19 $(n=2)$, mycoplasma pneumonia $(n=2)$, and gram positive cocci $(n=1)]$.

The CT findings were normal in 35.59\% (63/177) of the whole sample and 68.57\% (24/35) of the COVID-19positive patients. In the COVID-19-positive group, 50.00\% of the patients with normal CT findings were older than 16 years (12/24). The differences were statistically significant when compared to the other age groups (p $<0.01)$.

The CT findings were pathological in 64.41\% (114/177) of all patients (Table 2). Lung involvement was unilateral in 25.44\% (29/114) and bilateral in 74.56\% (85/114) of all patients. Of the COVID-19-positive patients, 45.45\% (5/11) had bilateral involvement of five lobes while 54.55\% (6/11) had unilateral single-lobe involvement ( $\mathrm{p}=0.304)$. Single-lobe involvement was mostly observed in the COVID-19-positive group, and the difference was statistically significant ( $\mathrm{p}<0.01$ ). Furthermore, in the COVID-19-positive group, 36.36\% $(4 / 11)$ of the patients had focal involvement (less than $25 \%$ of the lobe) $(p<0.01)$. In the COVID-19-negative group, involvement was extensive (more than $75 \%$ of the lobe) $(\mathrm{p}<0.01)$.

The presence of consolidation with GGO (45.45\%, 5/11) was the most frequently observed CT finding in the COVID-19-positive group, and the second most common finding was GGO without consolidation 
(36.36\%,4/11). In the COVID-19-negative group, consolidation with GGO was the most frequent CT finding (33.98\%, 35/103). Accompanying findings on CT are shown in Tables 3 and 4.

Table 2. Distribution of the main CT findings

\begin{tabular}{|c|c|c|}
\hline & $\begin{array}{l}\text { COVID-19-positive } \\
(\mathrm{n}=35)\end{array}$ & $\begin{array}{l}\text { COVID-19-negative } \\
\quad(\mathrm{n}=142)\end{array}$ \\
\hline Normal CT & $24(68.57 \%)^{*}$ & $39(27.46 \%)$ \\
\hline Pathological CT & $11(31.43 \%)$ & $103(72.53 \%)^{*}$ \\
\hline \multicolumn{3}{|l|}{ Number of lobes involved } \\
\hline Single lobe & $6(54.54 \%) *$ & $16(15.53 \%)$ \\
\hline Two lobes & - & $16(15.53 \%)$ \\
\hline Three lobes & - & $12(11.65 \%)$ \\
\hline Four lobes & - & $11(10.68 \%)$ \\
\hline Five lobes & $5(45.45 \%)$ & $48(46.60 \%)$ \\
\hline \multicolumn{3}{|l|}{ Involvement Type } \\
\hline GGO & $4(36.36 \%)^{*}$ & $14(13.59 \%)$ \\
\hline Consolidation & - & 26 (25.24\%)* \\
\hline GGO+consolidation & $5(45.45 \%) *$ & $35(33.98 \%)$ \\
\hline $\begin{array}{l}\text { Consolidation with the tree-in- } \\
\text { bud sign }\end{array}$ & $2(18.18 \%)$ & 27 (26.21\%) \\
\hline Other (only emphysema) & - & $1(0.97 \%)$ \\
\hline
\end{tabular}

${ }^{*} \mathrm{p}<0.01$, Student's t-test; GGO = Ground glass opacity

A total of 13 patients had focal emphysema in the lung parenchyma. In the COVID-19-negative group, only emphysema was observed in 1 patient while it was accompanied by other parenchyma findings in 12 patients. No emphysema was observed in the COVID-19-positive group.

The patients with only GGO were mostly present in the COVID-19-positive group ( $p<0.001)$. The reticular pattern was not detected in the patients with GGO alone. In the COVID-19-positive group, only 1 patient had the reticular pattern, and this patient also had an underlying primary disease (Stevens-Johnson syndrome). In contrast, in the COVID-19-negative group, the reticular pattern was mostly observed in the presence of GGO with consolidation $(17.48 \%, 18 / 103, \mathrm{p}<0.01)$. 
Table 3. Number of accompanying findings in CT (only pathological CT findings were considered)

\begin{tabular}{|l|c|c|}
\hline Accompanying findings & $\begin{array}{c}\text { COVID-19-positive } \\
(\mathrm{n}=11)\end{array}$ & $\begin{array}{c}\text { COVID-19-negative } \\
(\mathrm{n}=103)\end{array}$ \\
\hline Reticular pattern & $1(9.09 \%)$ & $\mathbf{3 6}(\mathbf{3 4 . 9 5 \% )} *$ \\
\hline Air bronchogram & $5(45.45 \%)$ & $47(45.63 \%)$ \\
\hline Bronchial wall thickening & $3(27.27 \%)$ & $34(33.01 \%)$ \\
\hline Bronchiectasis & $3(27.27 \%)$ & $24(23.30 \%)$ \\
\hline Emphysema & - & $\mathbf{1 3}(\mathbf{1 2 . 6 2 \%})^{*}$ \\
\hline Mosaic perfusion & $1(9.09 \%)$ & $\mathbf{2 7}(\mathbf{2 6 . 2 1 \%})$ \\
\hline Fibrotic bands & $1(9.09 \%)$ & $\mathbf{5 3}(\mathbf{5 1 . 4 6 \% )}$ \\
\hline Atelectasis & - & $\mathbf{1 0}(\mathbf{9 . 7 1 \%})^{*}$ \\
\hline Pleural effusion & - & $\mathbf{2 0}(\mathbf{1 9 . 4 2 \%})^{*}$ \\
\hline Halo sign & $\mathbf{1 ( 9 . 0 9 \% ) *}$ & $3(2.91 \%)$ \\
\hline Parenchymal nodule & $1(9.09 \%)$ & $5(4.85 \%)$ \\
\hline
\end{tabular}

${ }^{*} \mathrm{p}<0.01$, Student's t-test

Air bronchogram, which present as an additional finding in the presence of consolidation, was found in $45.61 \%$ (52/114) of the CT images, but there was no significant difference between the two groups $(p=0.304)$. Bronchial wall thickening was detected in $32.46 \%$ (37/114) of the CTs and was most often accompanied by consolidation with the tree-in-bud sign in the COVID-19-negative group ( $\mathrm{p}<0.001)$. Bronchiectasis was found in 23.68\% (27/114) of all CTs and observed more frequently in GGO with consolidation in the COVID-19positive group $(\mathrm{p}<0.01)$. Atelectasis and pleural effusion were not observed in the COVID-19-positive group $(\mathrm{p}<0.01)$. The halo sign was mostly seen in the COVID-19-positive group $(\mathrm{p}<0.01)$. Mosaic perfusion $(26.21 \%$, $27 / 103)$ and fibrotic bands (51.46\%,53/103) were detected at a significantly higher rate in the COVID-19negative group $(\mathrm{p}<0.01)$. However, there was no statistically significant difference between the two groups in terms of pulmonary parenchymal nodules $(\mathrm{p}=0.342)$. In Fig. 1 , we summarize the important findings that may lead to a diagnosis of COVID-19 based on CT findings.

There was 1 patient with a negative first test but a positive second test. Among the patients with a family history of COVID-19, the sensitivity values were calculated as 0.8831 for CT and 0.7945 for the RT-PCR test. In patients with underlying diseases, the sensitivity values were determined as 0.441 for CT and 0.863 for the RT-PCR test. 
Table 4. Distribution of the accompanying CT findings according to parenchymal involvement types and groups

\begin{tabular}{|c|c|c|c|}
\hline $\begin{array}{l}\text { Involvement type } \\
\text { in CT }\end{array}$ & Accompanying finding & $\begin{array}{l}\text { COVID-19-positive } \\
(\mathrm{n}=11)\end{array}$ & $\begin{array}{l}\text { COVID-19-negative } \\
\qquad(\mathrm{n}=103)\end{array}$ \\
\hline \multirow{9}{*}{ GGO+consolidation } & Reticular pattern & $1(9.09 \%)$ & $18(17.47 \%)^{*}$ \\
\hline & Air bronchogram & $2(18.18 \%)$ & $27(26.21 \%) *$ \\
\hline & Bronchial wall thickening & $2(18.18 \%)$ & $18(17.47 \%)$ \\
\hline & Bronchiectasis & $2(18.18 \%) *$ & $10(9.70 \%)$ \\
\hline & Mosaic perfusion & $1(9.09 \%)$ & $18(17.47 \%)^{*}$ \\
\hline & Fibrotic bands & $1(9.09 \%)$ & $32(31.07 \%) *$ \\
\hline & Atelectasis & - & $5(4.85 \%) *$ \\
\hline & Pleural effusion & - & $15(14.56 \%) *$ \\
\hline & Halo sign & $1(9.09 \%) *$ & - \\
\hline \multirow{9}{*}{$\begin{array}{l}\text { Consolidation with the } \\
\text { tree-in-bud sign }\end{array}$} & Reticular pattern & - & $12(11.65 \%)^{*}$ \\
\hline & Air bronchogram & $1(9.09 \%)$ & $11(10.68 \%)$ \\
\hline & Bronchial wall thickening & - & $12(11.65 \%) *$ \\
\hline & Bronchiectasis & $1(9.09 \%)$ & $11(10.68 \%)$ \\
\hline & Mosaic perfusion & - & $2(1.94 \%)$ \\
\hline & Fibrotic bands & - & $5(4.85 \%)$ \\
\hline & Atelectasis & - & $2(1.94 \%)$ \\
\hline & Pleural effusion & - & - \\
\hline & Halo sign & - & $3(2.91 \%)$ \\
\hline \multirow{9}{*}{ Consolidation } & Reticular pattern & - & $6(5.82 \%)$ \\
\hline & Air bronchogram & - & $9(8.74 \%)$ \\
\hline & Bronchial wall thickening & - & $4(3.88 \%)$ \\
\hline & Bronchiectasis & - & $3(2.91 \%)$ \\
\hline & Mosaic perfusion & - & $1(0.97 \%)$ \\
\hline & Fibrotic bands & - & $12(11.65 \%)$ \\
\hline & Atelectasis & - & $3(2.91 \%)$ \\
\hline & Pleural effusion & - & $5(4.85 \%) *$ \\
\hline & Halo sign & - & - \\
\hline \multirow[b]{2}{*}{ GGO } & Mosaic perfusion & $1(9.09 \%)$ & $6(5.82 \%)$ \\
\hline & Fibrotic bands & - & $4(3.88 \%)^{*}$ \\
\hline
\end{tabular}

${ }^{*} \mathrm{p}<0.01$, Student's t-test; GGO = Ground glass opacity 

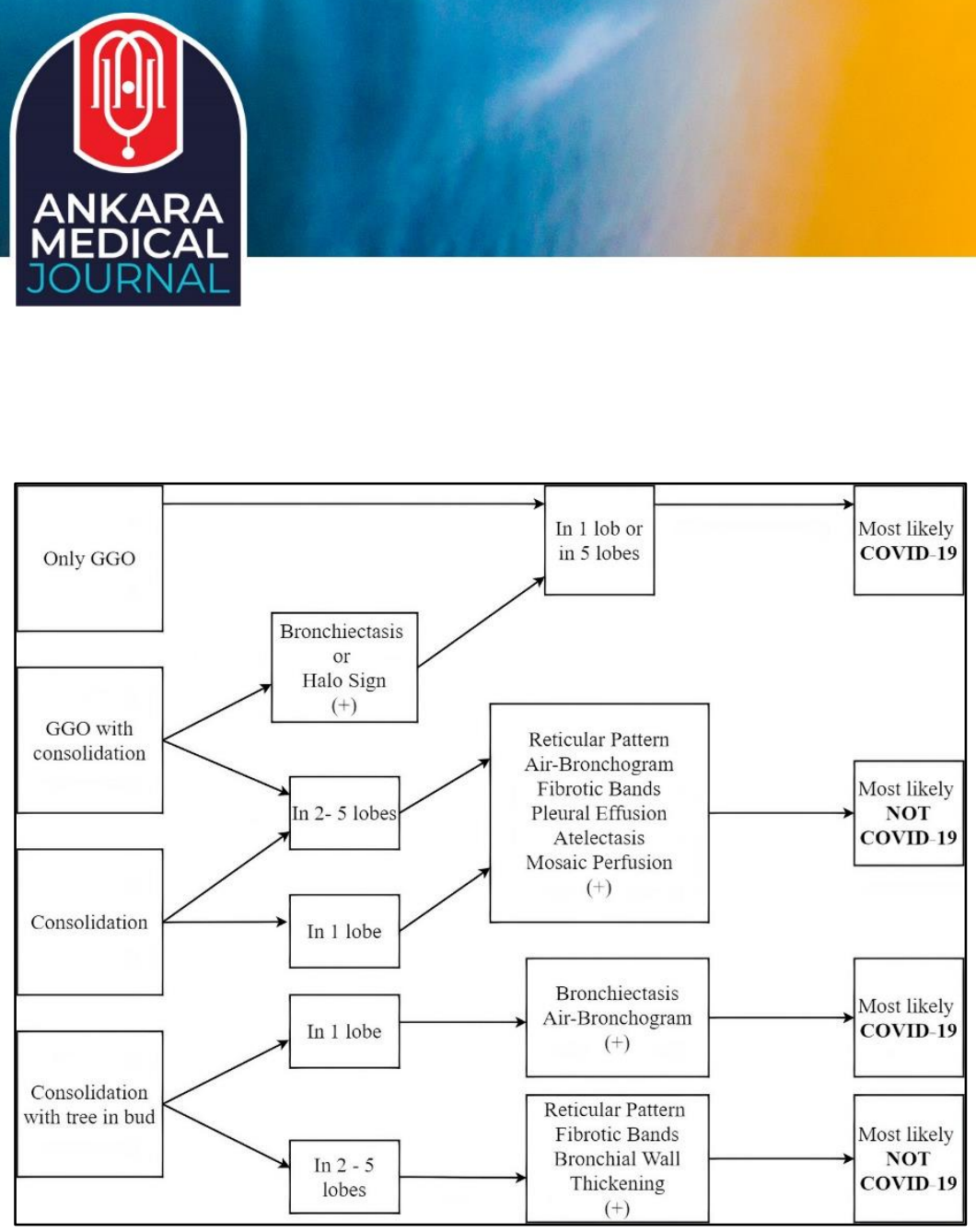

Figure 1. Possible diagnoses of the patients based on CT findings

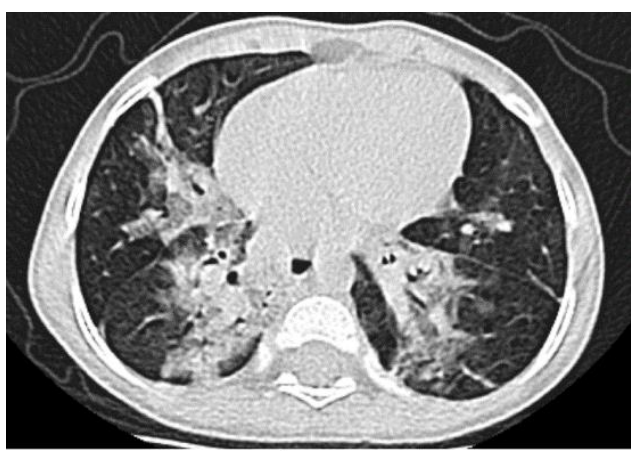

Figure 2. Axial CT image of three-year-old girl with a positive RTPCR test result. Bilateral diffuse ground glass opacity and consolidation, accompanied by air bronchogram are seen.

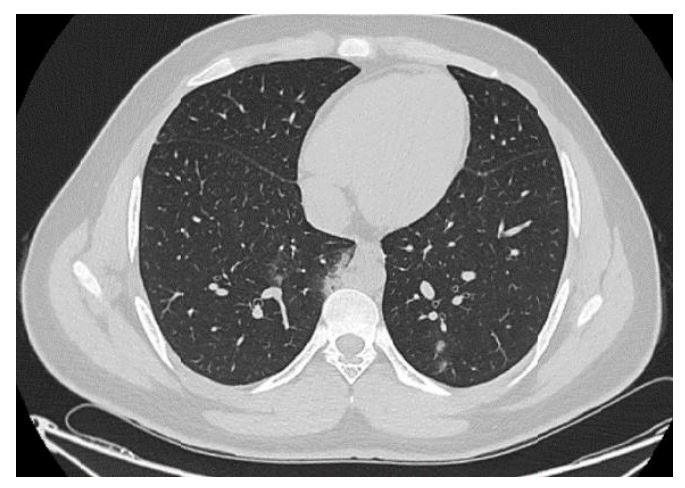

Figure 3. Axial CT image of a 16-year-old boy with a positive RT-PCR test result. Bilateral focal ground glass opacities are observed. 


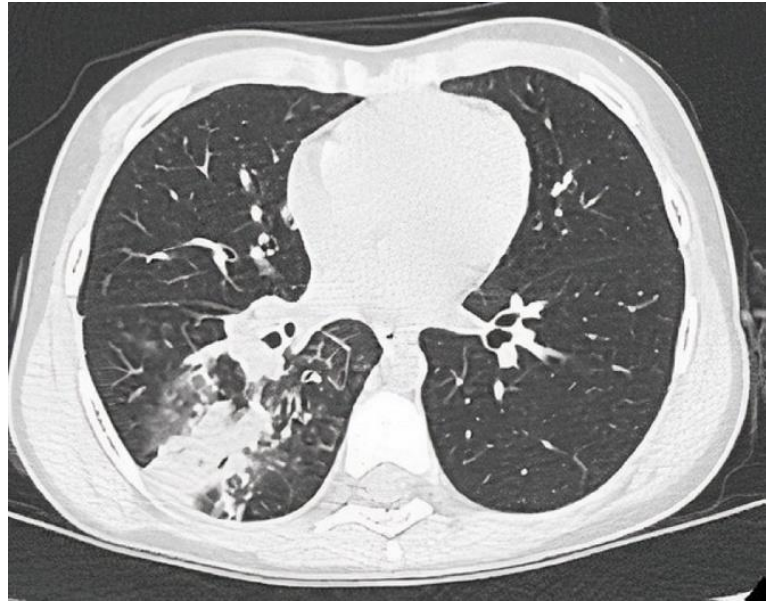

a

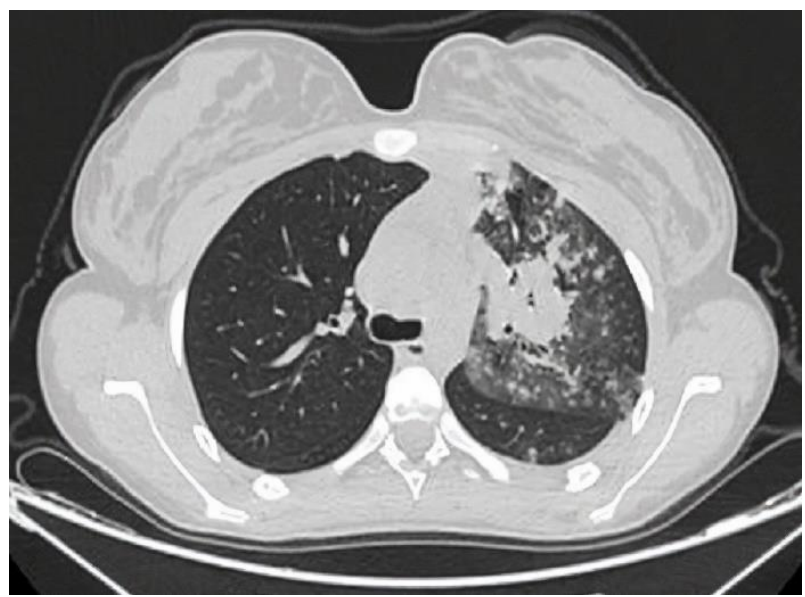

b

Figure 4. a, b. Axial CT images of (a) a seven-year-old girl with a positive RT-PCR test result, presenting with unilateral consolidation with the tree-in-bud sign in the right lower lobe and (b) a 14-year-old girl with a negative RT-PCR test result, revealing unilateral consolidation with the tree-in-bud sign in the left upper lobe.

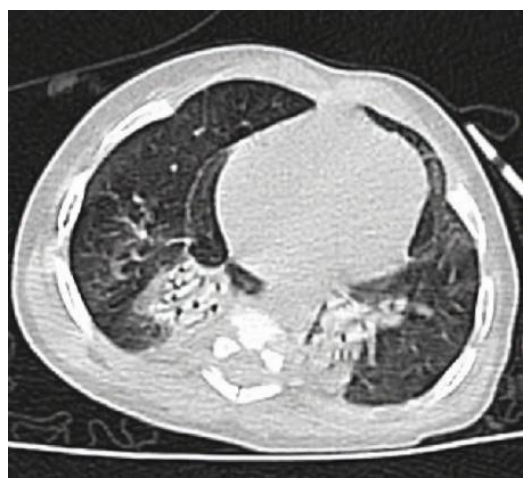

a

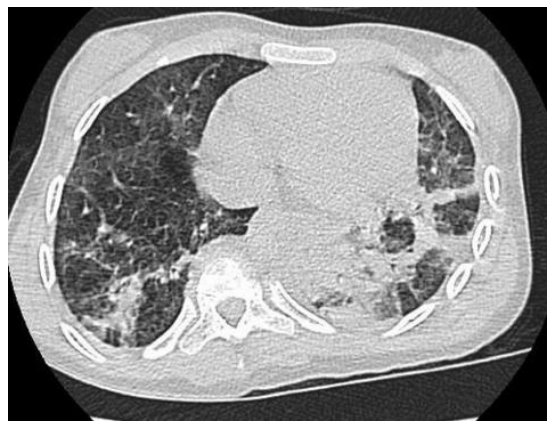

b

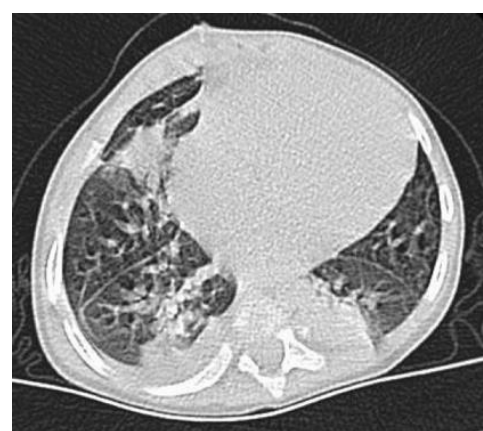

C

Figure 5. a-c. Axial CT images of (a) a 10-month-old boy with cytomegalovirus, presenting with bilateral consolidation accompanied by an air bronchogram; (b) a 12-year-old boy with haemophiles influenzae type B, presenting with consolidation, interseptal thickening, reticular pattern, atelectasis, and fibrotic bands; and (c) a two-year-old girl with Klebsiella pneumoniae, presenting with widespread consolidation, peribronchial thickening, and pleural effusion on the right side. 
Figure 6. Coronal CT image of an eight-year-old boy with white lung syndrome, presenting with bilateral consolidation, interseptal thickening, reticular pattern, fibrotic bands, and pneumothorax

\section{Discussion}

It is reported that CT findings are more moderate and typical CT findings are observed in a smaller number of pediatric patients with a milder clinical presentation than adult patients. ${ }^{14}$ While nearly $90 \%$ of adult COVID19 patients are reported to have pathological findings in thorax CT, studies with a limited number of pediatric patients have shown that $63 \%$ of the patients have pathological CT findings. ${ }^{15}$ In our series, we found CT findings only in $31.4 \%$ of patients who were confirmed to have COVID-19 based on RT-PCR testing, and this percentage is well below the rate reported in the literature. More CT findings being detected in adult patients may suggest that CT would more useful in pediatric patients as the age increases. However, it is remarkable that in our COVID-19-positive group, more than half the children with normal CT findings were older than 16 years. Thus, it can be concluded that patients older than 16 years of age can be followed up by evaluating the RT-PCR test result together with their clinic findings, and it is not necessary to perform a thorax CT scan. This finding is also supported by a previous report, indicating that normal CT findings are more frequently observed in children over 6 years of age. ${ }^{16}$

The presence of COVID-19 in the family is one of the most important factors to suspect the presence of the disease in the child. 7,8 We did not find any relationship between family history and the RT-PCR test result; however, found that there were more children with a family history of COVID-19 that also had a positive test RT-PCR test result. This suggests that children who do not have a previously known disease but start to show clinical signs at around the time when a member of their family receives a diagnosis of COVID-19 can be 
considered as high suspects for COVID-19. In these pediatric cases, the RT-PCR test and clinical follow-up may be sufficient without a thorax CT scan considering that we did not find any abnormal thorax CT finding in the majority of our patients.

In the literature, the most common CT finding in children is reported to be focal GGO, which is mostly observed in posterior lobes. ${ }^{17,18}$ In our sample, the most common CT finding was GGO with consolidation (Fig. 2). This may be due to the time interval between the onset of the patient's symptoms and CT because, unlike adults, a chest x-ray is the first preferred imaging method by clinicians to minimize radiation exposure in pediatric patients. Focal GGO was the other type of involvement we frequently detected (Fig. 3). The involvement in COVID-19 patients was either in a single lobe or in all lobes. Therefore, it can be considered that a preliminary diagnosis of COVID-19 can be excluded if two to four lobes are involved. In the presence of GGO alone or GGO with consolidation, single-lobe involvement should be a sign of COVID-19. If five lobes are involved, it is necessary to pay attention to the type of involvement in CT and accompanying findings. Similar to the literature, the presence of the halo sign suggests COVID-19 pneumonia although it is not a frequent finding among COVID19-positive patients. ${ }^{19}$ Bronchial wall changes are important in pediatric patients. It has also been reported that peribronchial spreading and bronchial wall thickening are frequently observed in pediatric patients. ${ }^{20} \mathrm{We}$ did not find a significant difference between the two groups in terms of bronchial wall thickness; however, we observed that if bronchial wall thickening accompanies consolidation with the tree-in-bud sign, the diagnosis of COVID-19 should be excluded. Although consolidation with the tree-in-bud sign resulting from peribronchial spreading can be seen in COVID-19 patients, it is known to occur through many other pneumonia agents (Fig. $4 \mathrm{a}, \mathrm{b})$.

Even in the absence of a family history of COVID-19, in hospitals specifically designated as pandemic centers, such as ours, patients admitted to all services are evaluated as high-risk patients. However, it can be stated that a radiological diagnosis becomes very difficult in the presence of accompanying respiratory, hematological, oncological, or neurological diseases. For example, in a patient receiving chemotherapy due to leukemia, it is necessary to investigate COVID-19 in the presence of newly developed clinical findings, such as fever and cough. However, many other viral, bacterial, or atypical agents, such as mycoplasma pneumonia, rhinovirus, respiratory syncytial virus (RSV), cytomegalovirus, H1N1, and adenovirus, can be frequently detected in the immunocompromised patient group. ${ }^{20}$ Although it has been suggested that children with underlying diseases may be more susceptible to COVID-1919, contrary to expectations, the test results were negative in the majority of the children (97.1\%) in our series. In $25 \%$ of our patients with negative RT-PCR test results, COVID-19 was definitively excluded by the determination of other pneumonia agents in the tracheal aspirate. In addition, 75\% of these patients had underlying diseases. Thus, it can be considered that protection from COVID-19 is easier than protection from many other pneumonia agents. It is clear that hospitalized children with chronic diseases, even those with immunodeficiency can be protected from COVID- 19 pneumonia as long as the necessary 
preventive measures are followed. In this patient group, where CT findings are more severe than those in COVID-19, some accompanying findings may be very useful in the differential diagnosis. It is known that consolidation is more intensive and bronchial wall thickening and pleural effusion are observed more frequently in patients with mycoplasma, adenovirus, influenza virus, and RSV pneumonia. ${ }^{12,19,21,22}$ According to our results, consolidation accompanied by air-bronchogram, bronchial wall thickening, pleural effusion, atelectasis, and fibrotic bands suggest other factors of pneumonia (Fig. 5. a). If there is GGO with consolidation accompanied by air-bronchogram, reticular pattern, and fibrotic bands in CT, the patient probably does not have COVID-19 (Fig. 5. b). We did not detect pleural effusion in any of our COVID-19-positive patients, which is consistent with the literature. We also did not observe atelectasis and detected mosaic perfusion only in 1 COVID-19-positive child. In the presence of pleural effusion and atelectasis, the patient's RT-PCR test is likely to be negative (Fig. 5. c). One of our patients, who had a negative first PCR test and a positive second test, had an underlying disease (Stevens-Johnson syndrome) (Fig. 6). In this patient, pneumothorax developed after intubation, and the CT findings were severe with diffused involvement being seen in the whole lung parenchyma(white lung syndrome). However, pleural effusion was not observed at any stage of the disease. This supports the assumption that the presence of pleural effusion will eliminate the preliminary diagnosis of COVID-19.

In adult series comparing the CT findings with the PCR test, the results are generally reported to be compatible. In addition, due to the possibility of the false negativity of the first test, it is emphasized that the test should be repeated in patients with typical CT findings. ${ }^{23,24}$ In accordance with the literature, in our sample, the CT sensitivity was higher than the RT-PCR test in children with a family history. However, we found that the sensitivity of the RT-PCR test was higher than CT in symptomatic patients with underlying diseases. Considering that RT-PCR was performed at least three times in all of our patients with suspected disease, false negativity due to technical reasons (difficulty of adaptation of the child during the test, etc.) can be considered as low. Besides, unlike adults, typical CT findings are less common and more likely to be normal in children, and therefore the RT-PCR test can be considered more reliable in this group. ${ }^{15,25}$ It has also been reported that the false positivity rate of CT is high in regions with low disease prevalence. ${ }^{26}$ It can be accepted that the sensitivity of repeated RT-PCR tests will be high in this carefully protected patient group. If all these data are taken into consideration, it will be appropriate to apply as few CT scans as possible in children. However, in the presence of high clinical suspicion, recurrent PCR tests are essential, and CT findings provide good guidance in the differential diagnosis and follow-up of severe disease. 24,27-30 The low number of patients in our series, especially compared to the adult series weakens the power of our study. Furthermore, we did not have knowledge of the time from the onset of symptoms to the application of CT. During this period, CT findings in COVID-19-positive patients may have changed. If CT was performed at a very early stage, it may have produced normal findings or at a late stage, consolidation may have intensified and involvement in the entire lung parenchyma may have occurred. ${ }^{3}$ 
Having a diagnosis of COVID-19 in the family significantly increases the risk of disease in pediatric patients. Underlying diseases are associated with other viral or atypical pneumonia agents than COVID-19. Patients with family history and no underlying disease, who present with single-lobe involvement, focal GGO alone, or GGO with consolidation on CT are most likely to have COVID-19. If CT findings are common and severe and also accompanied by pleural effusion and atelectasis, COVID-19 should be excluded from the preliminary diagnosis. Especially in the presence of an underlying disease, GGO with consolidation accompanied by air bronchogram, reticular pattern, atelectasis, pleural effusion, and/or fibrotic bands on CT, the patient is not likely to have COVID-19. The RT-PCR test is more sensitive than CT in children with underlying diseases. In the presence of high clinical suspicion, recurrent RT-PCR tests are essential, and CT is a good guiding tool in the differential diagnosis.

\section{Ethical considerations}

This retrospective analysis was approved by the institutional ethics committee (E1-20-458, 28.05.2020) and carried out in accordance with the principles of the Declaration of Helsinki.

\section{Conflict of interest}

The authors declare no conflict of interest. 


\section{References}

1. World Health Organization [Internet]. The Coronavirus Disease 2019 (COVID-19) Situation Report-51. https://www.who.int/docs/default-source/coronaviruse/situation-reports/20200311-sitrep-51-covid19.pdf?sfvrsn=1ba62e57_10. (Accessed: March 11, 2020).

2. World Health Organization [Internet]. The Coronavirus Disease 2019 (COVID-19) Situation Report-133. https://www.who.int/docs/default-source/coronaviruse/situation-reports/20200601-covid-19-sitrep133.pdf?sfvrsn=9a56f2ac_4. (Accessed: June 1, 2020).

3. Sun D, Li H, Lu XX, et al. Clinical features of severe pediatric patients with coronavirus disease 2019 in Wuhan: a single center's observational study. World J Pediatr 2020;19:1-9 (doi: 10.1007/s12519-02000354-4).

4. Lu X, Zhang L, Du H, et al. SARS-CoV-2 Infection in Children. N Engl J Med 2020;382:1663-65 (doi: 10.1056/NEJMc2005073).

5. Su L, Ma X, Yu H, et al. The Different Clinical Characteristics of Corona Virus Disease Cases Between Children and Their Families in China - The Character of Children With COVID-19. Emerg Microbes Infect 2020;9:707-13 (doi: 10.1080/22221751.2020.1744483).

6. Zhang T, Cui X, Zhao X, et al. Detectable SARS-CoV-2 viral RNA in feces of three children during recovery period of COVID-19 pneumonia. J Med Virol 2020;92:909-14 (doi:10.1002/jmv.25795).

7. Chang TH, Wu JL, Chang LY. Clinical characteristics and diagnostic challenges of pediatric COVID-19: A systematic review and meta-analysis. J Formos Med Assoc 2020;119:982-89 (doi:10.1016/j.jfma.2020.04.007).

8. Hasan A, Mehmood N, Fergie J. Coronavirus Disease (COVID-19) and Pediatric Patients: A Review of Epidemiology, Symptomatology, Laboratory and Imaging Results to Guide the Development of a Management Algorithm. Cureus 2020;12:e7485 (doi: 10.7759/cureus.7485).

9. Pan X, Chen D, Xia Y, et al. Asymptomatic cases in a family cluster with SARS-CoV-2 infection. Lancet Infect Dis 2020;20:410-11 (doi: 10.1016/S1473-3099(20)30114-6).

10. Li Y, Guo F, Cao Y, Li L, Guo Y. Insight into COVID-2019 for pediatricians. Pediatr Pulmonol 2020;55:1-4 (doi: 10.1002/ppul.24734).

11. He JL, Luo L, Luo ZD, et al. Diagnostic performance between CT and initial real-time RT-PCR for clinically suspected 2019 coronavirus disease (COVID-19) patients outside Wuhan, China. Respir Med 2020;168:105980 (doi: 10.1016/j.rmed.2020.105980).

12. Foust AM, Winant AJ, Chu WC, Das KM, Phillips GS, Lee EY. Pediatric SARS, H1N1, MERS, EVALI, and Now Coronavirus Disease (COVID-19) Pneumonia: What Radiologists Need to Know. AJR Am J Roentgenol 2020;215:736-44 (doi: 10.2214/AJR.20.23267). 
13. Turkey Ministry of Health [Internet]. COVID-19 (SARS-CoV-2 Infection) guide. https://hsgm.saglik.gov.tr/depo/birimler/goc_sagligi/covid19/rehber/COVID19_Rehberi20200414_eng_v4_002_14.05.2020.pdf. (Accessed: April 14, 2020).

14. Zimmermann P, Curtis N. Coronavirus Infections in Children Including COVID-19: An Overview of the Epidemiology, Clinical Features, Diagnosis, Treatment and Prevention Options in Children. Pediatr Infect Dis J 2020;39:355-68 (doi:10.1097/INF.0000000000002660).

15. de Souza TH, Nadal JA, Nogueira RJN, Pereira RM, Brandao MB. Clinical Manifestations of Children with COVID-19: a Systematic Review. Pediatr Pumonol 2020; 55: 1892-99 (doi: 10.1101/2020.04.01.20049833).

16. Zheng F, Liao C, Fan QH, et al. Clinical Characteristics of Children with Coronavirus Disease 2019 in Hubei, China. Curr Med Sci 2020;40:275-80 (doi: 10.1007/s11596-020-2172-6).

17. Duan YN, Zhu YQ, Tang LL, Qin J. CT features of novel coronavirus pneumonia (COVID-19) in children. Eur Radiol 2020; 30: 4427-33 (doi: 10.1007/s00330-020-06860-3).

18. Li W, Cui H, Li K, Fang Y, Li S. Chest computed tomography in children with COVID-19 respiratory infection. Pediatr Radiol 2020;50:796-99 (doi:10.1007/s00247-020-04656-7).

19. Xia W, Shao J, Peng X, Li Z, Hu D. Clinical and CT Features in Pediatric Patients With COVID-19 Infection: Different Points From Adults. Pediatr Pulmonol 2020;55:1169-74 (doi:10.1002/ppul.24718).

20. Chen A, Huang J, Liao Y, et al. Differences in Clinical and Imaging Presentation of Pediatric Patients with COVID-19 in Comparison with Adults. Radiology Cardiothoracic Imaging 2020;2:e200117 (doi:10.1148/ryct.2020200117).

21. Virkki R, Juven T, Rikalainen H, Svedstrom E, Mertsola J, Ruuskanen O. Differentiation of bacterial and viral pneumonia in children. Thorax 2002;57:438-41 (doi:10.1136/thorax.57.5.438).

22. Qiu H, Wu J, Hong L, Luo Y, Song Q, Chen D. Clinical and epidemiological features of 36 children with coronavirus disease 2019 (COVID-19) in Zhejiang, China: an observational cohort study. Lancet Infect Dis 2020;20:689-96 (doi:10.1016/S1473-3099(20)30198-5).

23. Salehi S, Abedi A, Balakrishnan S, Gholamrezanezhad A. Coronavirus Disease 2019 (COVID-19): A Systematic Review of Imaging Findings in 919 Patients. AJR Am J Roentgenol 2020;215:87-93 (doi:10.2214/AJR.20.23034).

24. Fang Y, Zhang H, Xie J, et al. Sensitivity of chest CT for COVID-19: comparison to RT-PCR. Radiology 2020; 296:115-7 (doi:10.1148/radiol.2020200432).

25. Y Lu, H Wen, D Rong, Z Zhou, H Liu. Clinical Characteristics and Radiological Features of Children Infected With the 2019 Novel Coronavirus. Clin Radiol 2020;75:520-25 (doi: 10.1016/j.crad.2020.04.010).

26. Kim H, Hong H, Yoon SH. Diagnostic Performance of CT and Reverse Transcriptase-Polymerase Chain Reaction for Coronavirus Disease 2019: A Meta-Analysis. Radiology 2020;296:145-55 (doi:10.1148/radiol.2020201343). 
27. Xie X, Zhong Z, Zhao W, Zheng C, Wang F, Liu J. Chest CT for typical 2019-nCoV pneumonia: relationship to negative RT-PCR testing. Radiology 2020;296:41-45 (doi:10.1148/radiol.2020200343).

28. Feng K, Yun YX, Wang XF, et al. Analysis of CT features of 15 Children with 2019 novel coronavirus infection. Zhonghua Er Ke Za Zhi 2020;58:E007 (doi:10.3760/cma.j.issn.0578-1310.2020.0007).

29. Hosseiny M, Kooraki S, Gholamrezanezhad A, Reddy S, Myers L. Radiology Perspective of Coronavirus Disease 2019 (COVID-19): Lessons From Severe Acute Respiratory Syndrome and Middle East Respiratory Syndrome. AJR Am J Roentgenol 2020;214:1078-82 (doi:10.2214/AJR.20.22969).

30. Chen D, Jiang X, Hong Y, et al. Can Chest CT Features Distinguish Patients With Negative From Those With Positive Initial RT-PCR Results for Coronavirus Disease (COVID-19)? AJR Am J Roentgenol 2020;5:1-5 (doi: 10.2214/AJR.20.23012). 